\title{
Virus-Associated Biomarkers in Oropharyngeal and Nasopharyngeal Cancers and Recurrent Respiratory Papillomatosis
}

\author{
Shigeyuki Murono (D)
}

Citation: Murono, S.

Virus-Associated Biomarkers in Oropharyngeal and Nasopharyngeal Cancers and Recurrent Respiratory Papillomatosis. Microorganisms 2021, 9,1150. https://doi.org/10.3390/ microorganisms 9061150

Academic Editors: Hirokazu Kimura and Jacob Bornstein

Received: 2 April 2021

Accepted: 25 May 2021

Published: 27 May 2021

Publisher's Note: MDPI stays neutral with regard to jurisdictional claims in published maps and institutional affiliations.

Copyright: (C) 2021 by the author. Licensee MDPI, Basel, Switzerland. This article is an open access article distributed under the terms and conditions of the Creative Commons Attribution (CC BY) license (https:/ / creativecommons.org/licenses/by/ $4.0 /)$.
Department of Otolaryngology, Fukushima Medical University, Fukushima 960-1295, Japan; murono@fmu.ac.jp; Tel.: +81-24-547-1321

\begin{abstract}
Nasopharyngeal cancer (NPC) is known to be associated with Epstein-Barr virus (EBV). Pre-treatment and post-treatment detection of plasma cell-free EBV DNA has been shown to be useful as a diagnostic as well as a prognostic factor in NPC. On the other hand, the incidence of human papillomavirus (HPV)-associated oropharyngeal cancer (OPC) is increasing. In contrast to cervical cancer, which is classically known to be an HPV-associated malignancy, HPV testing is not clinically applied for OPC, except for p16 immunostaining as a surrogate marker of HPV infection. One of the major characteristics of HPV-associated OPC is its association with a good prognosis compared with non-HPV-associated OPC. However, some patients still have a poor prognosis. Another characteristic of HPV-associated OPC is the distinct risk factor of high sexual activity. Establishing a biomarker for the prediction of the prognosis before and/or after initial treatment, as well as for diagnosis in populations at high risk, is of marked interest. With this background, HPV DNA detection in plasma and oral rinses has become an area of focus. In this review, the current significance of HPV DNA detection in plasma and oral rinse samples, as well as serum HPV antibody levels, is evaluated.
\end{abstract}

Keywords: human papillomavirus; oropharyngeal cancer; DNA; plasma; oral rinse; biomarker; recurrent respiratory papillomatosis

\section{The First Human Virus-Associated Cancer: Epstein-Barr Virus and Nasopharyngeal Cancer}

\subsection{Plasma Cell-Free Epstein-Barr Virus DNA in Nasopharyngeal Cancer Patients}

Classically, the most well-known virus-associated head and neck cancer is nasopharyngeal cancer (NPC), which is closely associated with Epstein-Barr virus (EBV). In situ hybridization for EBV-encoded RNA (EBER) can clearly identify EBV-infected tumor cells, whereas elevation of the serum EBV titer has been useful as a diagnostic adjunct [1,2]. In addition, quantitation of plasma/serum cell-free EBV DNA has had an impact as a biomarker for NPC diagnosis and prognosis after treatment [3]. Lo et al. showed for the first time that cell-free EBV DNA could be detected in 55 (96\%) of 57 patients with NPC [3]. In addition, patients with undetectable post-treatment plasma EBV DNA showed no clinically residual tumors, whereas patients with detectable post-treatment plasma EBV DNA showed residual or recurrent tumors [3]. A meta-analysis of 15 published papers revealed that the sensitivity and specificity of plasma EBV DNA were 91\% and 93\%, respectively, which were higher than those of serum EBV DNA, at $84 \%$ and $76 \%$, respectively [4]. With respect to prognosis, a meta-analysis of 14 published papers revealed that both patients with high plasma EBV DNA before treatment and those with persistent plasma EBV DNA after treatment showed significantly poorer overall survival (hazard ratio (HR), 2.81; 95\% CI, 2.44-3.24; $p<0.00001$, and HR, 4.26; 95\% CI, 3.26-5.57; $p<0.00001$, respectively) [5]. Wang et al. reported that a higher pre-treatment plasma EBV DNA level was associated with poorer overall survival ( $p=0.0295)$ and relapse-free survival $(p=0.0163)$ [6]. Furthermore, the residual post-treatment plasma EBV level was closely associated with poorer overall 
survival $(p<0.0001)$ and relapse-free survival $(p<0.0001)$ [7]. Based on these findings, clinical studies investigating the significance of adjuvant chemotherapy in patients with residual plasma EBV DNA are ongoing.

\subsection{Other EBV-Associated Malignant Tumor}

Extranodal natural killer/T-cell lymphoma, nasal type (ENKL) is another well-known EBV-associated head and neck malignancy. Lei et al. first reported that plasma EBV DNA was a useful tumor marker for the diagnosis, disease monitoring, and prediction of outcomes in patients with ENKL [8]. Suzuki et al. showed that pre-treatment plasma EBV DNA was detected in $14(44 \%)$ of 32 patients with ENKL [9]. On the other hand, Wang et al. reported that pre-treatment plasma EBV DNA was detected in $58(84 \%)$ of 69 stage I and stage II ENKL patients, which was higher than the results of previous studies [10]. Suzuki et al. also showed better 3-year overall survival in patients who were negative for pre-treatment plasma EBV DNA than those who were positive for it [9]. Similarly, patients with low pre-treatment plasma EBV DNA showed better 3-year overall survival and 3-year progression-free survival than those with high pre-treatment plasma EBV DNA ( $97 \%$ vs. $66 \%$ and $79 \%$ vs. $52 \%$, respectively) [10]. Furthermore, patients who were positive for post-treatment plasma EBV-DNA showed poorer 3-year overall survival and 3-year progression-free survival than those who were negative for post-treatment plasma EBV DNA ( $92 \%$ vs. $70 \%$ and $78 \%$ vs. $51 \%$, respectively) [10]. These results indicate that plasma EBV DNA can be a biomarker not only of NPC but also of ENKL.

\section{Human Papillomavirus as a Causative Agent Not Only for Cervical Cancer, but also for Oropharyngeal Cancer}

Head and neck cancer has typically been diagnosed in older patients, in association with the heavy use of tobacco and alcohol [11]. On the other hand, it has become apparent that human papillomavirus (HPV) is a principal cause of a distinct form of oropharyngeal cancer (OPC) [12]. The incidence of head and neck cancer is slowly declining globally, in part because of decreased use of tobacco [11,13]. Conversely, cases of HPV-associated OPC are increasing, predominantly among younger people in North America and northern Europe-Chaturvedi et al. showed that the HPV prevalence in OPC patients significantly increased from $16.3 \%$ in the 1980 s to more than $72.7 \%$ in the 2000 s in the United States $[11,14]$.

With an increasing incidence of HPV-positive OPC, the projected annual number of OPC patients has surpassed that of cervical cancer patients since $2010[6,14]$. On the other hand, HPV has been recognized as a causative agent of cervical cancer. Currently, this strong association is clinically applied to two very effective prevention strategies for cervical cancer: cervical screening with primary HPV testing and vaccination against HPV [15]. In 2020, it was proven for the first time that quadrivalent HPV vaccination was associated with a substantially reduced risk of invasive cervical cancer at the population level among Swedish girls and women aged from 10 to 30 years old [16]. On the other hand, the effectiveness of prophylactic HPV vaccination is less well defined for OPC than for anogenital and cervical cancers [11].

From the perspective of cervical cancer screening, cytology-based screening programs have been implemented in many countries. On the other hand, various HPV-based screening methods-including HPV DNA tests by direct genomic detection or by amplification of a viral DNA fragment using polymerase chain reaction, and HPV mRNA tests to detect the expression of $E 6$ and $E 7$ viral oncogenes-have been found to have higher sensitivity than cytology but somewhat lower specificity in cervical cancer [17]. Therefore, co-testing with cytology and HPV, and lately HPV testing alone, have been proposed for cervical cancer screening [17]. Furthermore, self-sampling for HPV testing has been developed [17]. However, no approved HPV-based screening, except for p16 immunostaining as a surrogate marker of HPV infection in histopathological diagnosis, is available for HPV-positive OPC. In this review, we focus on viral DNA in virus-associated head and neck cancer, and summarize the usefulness of HPV DNA detection in oral rinse samples, as well as in plasma, as a diagnostic and prognostic marker of HPV-associated OPC. 


\section{Plasma Cell-Free HPV DNA in Oropharyngeal Cancer Patients}

\subsection{Oropharyngeal Cancer}

The question of whether plasma/serum cell-free HPV DNA is useful as a biomarker of HPV-associated OPC, like EBV DNA in NPC, is of marked interest. Capone et al. first demonstrated the detection and quantitation of HPV DNA in the sera of four out of nine HPV-associated OPC patients [18]. However, most reports were published in the 2010s, as reviewed by Jensen et al. in 2018 [19]. Although the pre-treatment sensitivity was around $65 \%$ in earlier reports, it has reached $90 \%$ in recent reports (Table 1) [20-24]. In addition, some reports have demonstrated the quantitation of plasma HPV DNA viral load, which may present clinical relevance (Table 2) $[20,22,24]$.

Table 1. HPV DNA detection in pre- and/or post-treatment plasma in oropharyngeal cancer patients.

\begin{tabular}{|c|c|c|c|c|c|c|}
\hline $\begin{array}{c}\text { Author } \\
\text { (Reference) }\end{array}$ & Year & $\begin{array}{l}\text { Number of Cases } \\
\text { (HPV-Positive: } \\
\text { HPV-Negative) }\end{array}$ & $\begin{array}{l}\text { Tissue HPV } \\
\text { Status }\end{array}$ & $\begin{array}{l}\text { Detection } \\
\text { Method }\end{array}$ & Sensitivity ${ }^{1}$ & Specificity $^{1}$ \\
\hline Cao [20] & 2012 & $\begin{aligned} & \text { HPV-positive OPC }{ }^{2} 40 \\
+ & \text { HPV-negative HNC } \\
& 324\end{aligned}$ & p16 & $\mathrm{qPCR}^{4}$ & $65 \%$ & $100 \%$ \\
\hline Ahn [21] & 2014 & $\begin{array}{c}\text { OPC } 87(75: 12) \\
+ \text { unknown primary } 6(6: 0)\end{array}$ & $\mathrm{ISH}^{5}$ or $\mathrm{p} 16$ & qPCR & $\begin{array}{c}67 \% \\
\text { (pre-treatment) } \\
55 \% \\
\text { (post-treatment) }\end{array}$ & $\begin{array}{c}100 \% \\
\text { (pre-treatment) } \\
96 \% \\
\text { (post-treatment) }\end{array}$ \\
\hline Dahlstrom [22] & 2015 & $\begin{array}{c}\text { OPC } 141 \text { (114:27) } \\
\text { (Test cohort) }\end{array}$ & PCR & qPCR & $61 \%$ & $67 \%$ \\
\hline Lee [23] & 2017 & $\begin{array}{c}\text { OPC } 47+\mathrm{LC}^{6} 4+\mathrm{HPC}^{7} 4 \\
(27: 28) \\
\text { (Validation cohort) } \\
\text { OPC } 28+\mathrm{LC} 4+\mathrm{HPC} 1 \\
(20: 13)\end{array}$ & p16 & $\begin{array}{l}\text { Amplicon-based } \\
\text { next generation } \\
\text { sequencing assay }\end{array}$ & $\begin{array}{l}100 \% \\
90 \%\end{array}$ & $\begin{array}{l}93 \% \\
100 \%\end{array}$ \\
\hline Chera [24] & 2019 & $\begin{array}{c}\text { OPC } 103 \text { (44:10:49 unknown) } \\
+\mathrm{HV}^{8} 103\end{array}$ & p16 & Digital PCR & $89 \%$ & $97 \%$ \\
\hline
\end{tabular}

${ }^{1}$ Sensitivity and specificity of HPV DNA detection in plasma in regard to tumor tissue HPV status, ${ }^{2}$ Oropharyngeal cancer, ${ }^{3}$ Head and neck cancer, ${ }^{4}$ Quantitative PCR, ${ }^{5}$ In situ hybridization, ${ }^{6}$ Laryngeal cancer, ${ }^{7}$ Hypopharyngeal cancer, ${ }^{8}$ Healthy volunteer.

Table 2. HPV DNA viral load in pre-treatment plasma in oropharyngeal cancer patients.

\begin{tabular}{|c|c|c|c|}
\hline $\begin{array}{c}\text { Author } \\
\text { [Reference] }\end{array}$ & Year & Sample & HPV DNA Viral Load \\
\hline Cao [20] & 2012 & plasma & $\begin{array}{c}<500 \text { copies } / \mathrm{mL} \text { in } 13 \text { patients and }>500 \text { copies } / \mathrm{mL} \text { in } 13 \text { patients among } 26 \text { patients } \\
\text { with detectable HPV DNA }\end{array}$ \\
\hline Dahlstrom [22] & 2015 & plasma & $\begin{array}{c}0 \text { copies } / \mathrm{mL} \text { in } 114 \text { patients, } 0.1 \text { to }<10 \text { copies } / \mathrm{mL} \text { in } 23 \text { patients, } 10 \text { to }<100 \\
\text { copies } / \mathrm{mL} \text { in } 59 \text { patients; } 100 \text { to }<1000 \text { copies } / \mathrm{mL} \text { in } 47 \text { patients and } \geq 1000 \\
\text { copies } / \mathrm{mL} \text { in } 19 \text { patients among all } 262 \mathrm{OPC}^{1} \text { patients, including } 114 \mathrm{HPV} \text {-positive, } \\
27 \mathrm{HPV} \text {-negative and } 121 \text { with patients missing data }\end{array}$ \\
\hline Chera [24] & 2019 & plasma & $\begin{array}{c}\text { Median } 419 \text { copies } / \mathrm{mL} \text {, ranging from } 8 \text { to } 22,579 \text {, in } 84 \mathrm{HPV} \text {-positive OPC patients } \\
\text { with detectable HPV16 DNA in plasma }\end{array}$ \\
\hline
\end{tabular}

${ }^{1}$ Oropharyngeal cancer.

Interestingly, plasma HPV DNA reflects the tumor status, as observed in NPC, with Cao et al. demonstrating that serial measurements in 14 patients showed a rapid decline in HPV DNA, which became undetectable on the completion of radiotherapy, whereas the HPV DNA level increased to a detectable level at metastasis in three patients [20]. Similarly, Lee et al. reported that 36 patients who were negative for post-treatment HPV DNA showed no recurrence, whereas the remaining patient, who was positive for posttreatment HPV DNA, showed recurrence and metastasis [23]. These results suggest that post-treatment plasma HPV DNA correlates with the clinical response. However, pooled analyses from four studies demonstrated that the sensitivity and specificity of the residual detection of plasma HPV DNA for the recurrence of HPV-associated OPC were $54 \%$ and 98\%, respectively [19]. On the other hand, the clearance of plasma HPV DNA has recently 
become an area of focus. Chera et al. reported that favorable clearance, defined as having a high baseline plasma HPV DNA copy number ( $>200$ copies $/ \mathrm{mL}$ ) and $>95 \%$ clearance of plasma HPV DNA by day 28 of chemoradiotherapy, led to better survival with no persistent or recurrent regional disease after the initial treatment [24].

\subsection{Cervical Cancer}

As mentioned before, cervical cancer is known to be associated with HPV. However, in contrast to OPC, there have been limited reports investigating the usefulness of plasma/serum HPV DNA in cervical cancer. In early reports, positivity was lowPornthanakasem et al. showed that six (12\%) out of 50 patients and Dong et al. showed $12(7 \%)$ out of 175 patients tested positive $[25,26]$. Results have recently improved, with Jeannot et al. showing 61 (87\%) of 70 patients and Cheung et al. showed $85(62 \%)$ of 135 patients $[27,28]$.

\section{Pre-Treatment HPV DNA in Oral Rinses of Oropharyngeal Cancer Patients}

As mentioned before, the association of HPV with cervical cancer is clinically applied to cervical screening with primary HPV testing. On the other hand, such a screening system has yet to be established for OPC, although the incidence of HPV-associated OPC has been increasing. From this perspective, oral rinses or saliva may be attractive samples due to the fact that their collection is non-invasive.

Smith et al. reported in 2004 that the sensitivity and specificity of HPV DNA detection in oral rinse samples were $58 \%$ and $85 \%$, respectively, when combining 67 OPC and 126 oral cancer patients [29]. Several reports describing the detection of HPV DNA in oral rinses or saliva have been published since then. Some focused on OPC, whereas others focused on OPC and oral cancer or all head and neck cancers, as shown in Table 3 [21,29-47]. Gipson et al. reviewed seven studies, including two using swabs, and demonstrated that the combined sensitivity and specificity were $72 \%(95 \%$ CI, 45-89) and 92\% (95\% CI, 82-97), respectively, in 2018 [46]. Figure 1 presents previous reports, and shows that the specificity was $90 \%$ or higher in most studies, whereas the sensitivity varied among studies, with the highest being $93 \%$.

As mentioned before, the quantitation of viral load may present clinical relevance in plasma. Similarly, some reports have investigated the HPV DNA viral load in oral rinse samples (Table 4) [32,36,44]. However, unlike studies of plasma, viral load seems to vary among these studies.

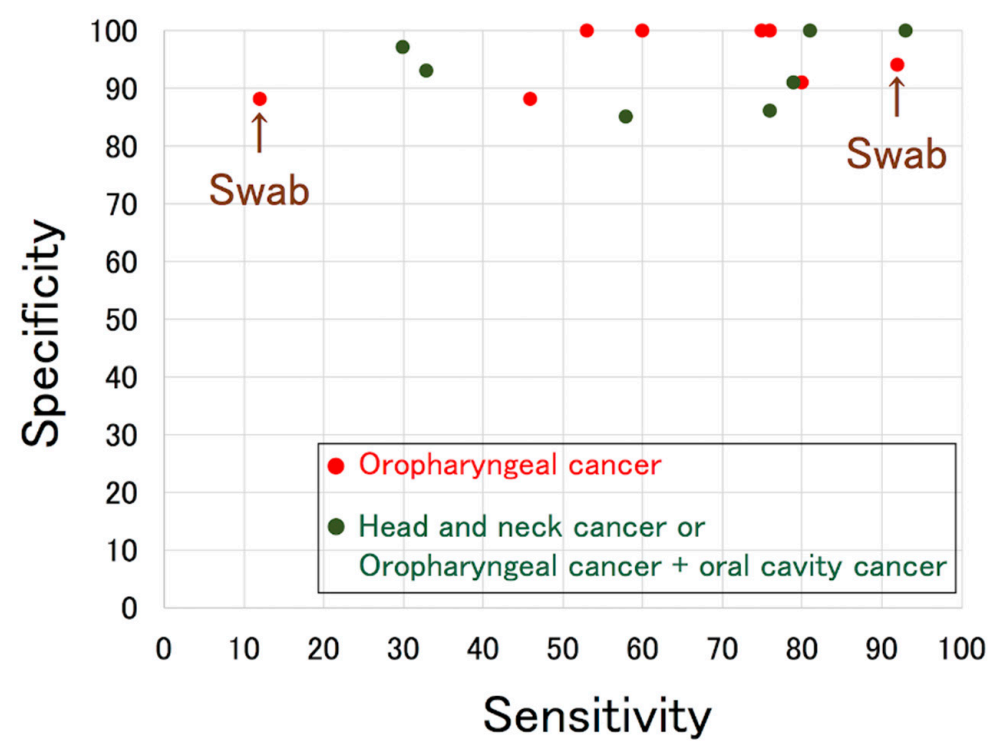

Figure 1. Scatter plot of sensitivity and specificity of pre-treatment HPV DNA detection in oral rinse in each study of oropharyngeal cancer. "Swab" indicates samples collected by swab. 
Table 3. HPV DNA detection in pre-treatment oral rinse in oropharyngeal cancer patients.

\begin{tabular}{|c|c|c|c|c|c|c|}
\hline $\begin{array}{c}\text { Author } \\
\text { [Reference] }\end{array}$ & Year & $\begin{array}{l}\text { Number of Cases } \\
\text { (HPV-Positive: } \\
\text { HPV-Negative) }\end{array}$ & $\begin{array}{l}\text { Tissue HPV } \\
\text { Status }\end{array}$ & $\begin{array}{l}\text { Detection } \\
\text { Method }\end{array}$ & Sensitivity $^{2}$ & Specificity $^{2}$ \\
\hline Smith [29] & 2004 & $\begin{aligned} & \mathrm{OPC}^{3} 67(25: 42) \\
+ & \mathrm{OCC}^{4} 126(13: 113)\end{aligned}$ & $\begin{array}{l}\text { PCR and direct } \\
\text { sequencing }\end{array}$ & $\begin{array}{l}\text { PCR and direct } \\
\text { sequencing }\end{array}$ & $58 \%$ & $85 \%$ \\
\hline D'Souza [30] & 2007 & OPC $100(72: 28)$ & $\mathrm{ISH}^{5}$ & PCR & $\begin{array}{c}32 \% \\
\text { (HPV16-positive rate) }\end{array}$ & $\mathrm{NA}^{6}$ \\
\hline Gillison [31]* & 2008 & $\begin{array}{c}\mathrm{HNC}^{7} 240(92: 148) \\
\text { including OPC } 114 \text { (82:32) }\end{array}$ & ISH & $\mathrm{qPCR}^{8}$ & 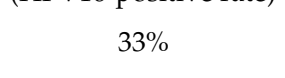 & $93 \%$ \\
\hline Agrawal [32] & 2008 & $\begin{array}{c}\text { HNC } 135 \text { (44:91) } \\
\text { including OPC } 52 \text { (41:11) }\end{array}$ & ISH & $\begin{array}{l}\text { PCR + linear } \\
\text { probe assay }\end{array}$ & $\begin{array}{c}30 \% \\
\text { (HPV16) }\end{array}$ & $\begin{array}{c}97 \% \\
(\text { HPV16) }\end{array}$ \\
\hline Koslabova [33] * & 2013 & OPC 118 + OCC 24 (84:58) & PCR & $\begin{array}{l}\text { PCR + line blot } \\
\text { hybridization }\end{array}$ & $76 \%$ & $86 \%$ \\
\hline Ahn [21] * & 2014 & $\begin{array}{l}\text { OPC } 87(75: 12) \\
+\mathrm{UP}^{9} 6(6: 0)\end{array}$ & qPCR & qPCR & $53 \%$ & $100 \%$ \\
\hline D'Souza [34] & 2014 & HPV-positive OPC 164 & ISH or p16 & $\mathrm{PCR}$ and $\mathrm{qPCR}$ & $\begin{array}{c}61 \% \\
\text { (oncogenic } \\
\text { HPV-positive rate) }\end{array}$ & NA \\
\hline Dang [35] & 2015 & Mostly OPC 56 (48:8) & p16 & qPCR & $46 \%$ & $88 \%$ \\
\hline Rettig [36] & 2015 & HPV-positive OPC 124 & ISH and p16 & $\begin{array}{l}\text { PCR + line blot } \\
\text { hybridization }\end{array}$ & $\begin{array}{c}54 \% \\
\text { (HPV16-positive rate) }\end{array}$ & NA \\
\hline Tsao $[37] * 1$ & 2016 & OPC $144(128: 16)$ & ISH or PCR & $\begin{array}{c}\text { PCR + Easy-Chip } \\
\text { HPV blot }\end{array}$ & 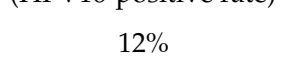 & $88 \%$ \\
\hline Chai [38]* & 2016 & $\begin{array}{c}\text { HNC } 82 \text { (42:40) } \\
\text { including OPC } 50 \text { (38:12) }\end{array}$ & p16 and ISH & qPCR & $93 \%$ & $100 \%$ \\
\hline $\begin{array}{c}\text { Imai [39] } \\
\text { Yoshida }\end{array}$ & 2016 & OPC $15(5: 10)$ & p16 and ISH & $\begin{array}{c}\text { Cobas } \\
\text { Auto-nested PCR }\end{array}$ & $\begin{array}{l}60 \% \\
75 \%\end{array}$ & $\begin{array}{l}100 \% \\
100 \%\end{array}$ \\
\hline Isaac $[41] *$, & 2017 & OPC 52 (36:16) & p16 & $\begin{array}{l}\text { Droplet digital } \\
\text { PCR }\end{array}$ & $92 \%$ & $94 \%$ \\
\hline Rosenthal [42] & 2017 & OPC 45 + OCC 61 (43:63) & p16 & Cobas & $79 \%$ & $91 \%$ \\
\hline Wasserman [43] & 2017 & OPC $24(17: 7)$ & p16 & Nested PCR & $76 \%$ & $100 \%$ \\
\hline Tang [44] & 2019 & OPC 121 (89:32) & p16 & qPCR & $80 \%$ & $91 \%$ \\
\hline Fakhry [45] & 2019 & $\begin{array}{l}\text { OPC } 217(187: 30) \\
+ \text { OCC } 170(7: 163) \\
+ \text { + UP } 9(8: 1)\end{array}$ & mRNA & $\begin{array}{l}\text { PCR + line blot } \\
\text { hybridization }\end{array}$ & $84 \%$ & $88 \%$ \\
\hline
\end{tabular}

${ }^{1}$ Samples were collected using swabs in these studies. ${ }^{2}$ Sensitivity and specificity of HPV DNA detection in oral rinse samples in regard to tumor tissue HPV status, ${ }^{3}$ Oropharyngeal cancer, ${ }^{4}$ Oral cavity cancer, ${ }^{5}$ In situ hybridization, ${ }^{6}$ Not available, ${ }^{7}$ Head and neck cancer, ${ }^{8}$ Quantitative PCR, ${ }^{9}$ Unknown primary, ${ }^{*}$ References cited by combined sensitivity and specificity in [46]. Modifed from [47] with permission by the Society of Oto-Rhino-Laryngology, Tokyo.

Table 4. HPV DNA viral load in pre-treatment oral rinse in oropharyngeal cancer patients.

\begin{tabular}{cccc}
\hline Author [Reference] & Year & Sample & HPV DNA Viral Load \\
\hline Agrawal [32] & 2008 & Oral rinse & $\begin{array}{c}\text { Median 4.6 copies } / 1000 \text { cells, ranging from } \\
0.2 \text { to 19, in positive samples }\end{array}$ \\
Rettig [36] & 2015 & Oral rinse & $\begin{array}{c}\text { Median 161 copies } / 2 \mu \text {, ranging from 21 to 846 } \\
\text { Mean 774.1 copies /50 ng in advanced stage of }\end{array}$ \\
Tang [44] & 2019 & Oral rinse & $\begin{array}{c}\text { HPV-positive OPC } \\
\text { and 232.0 copies/50 ng in } \\
\text { early stage of HPV-positive OPC }\end{array}$ \\
\hline
\end{tabular}

${ }^{1}$ Oropharyngeal cancer.

\section{Post-Treatment HPV DNA in Oral Rinse of Oropharyngeal Cancer Patients}

Residual plasma EBV DNA after the completion of initial treatment is associated with a poorer prognosis in NPC patients. Similarly, as mentioned before, residual plasma HPV DNA could be a predictive indicator of a poorer prognosis in HPV-associated OPC patients. From a similar perspective, the dynamics of HPV DNA in oral rinses after treatment has been of marked interest. Chuang et al. reported that four of 20 patients with positive pre-treatment HPV DNA ultimately developed recurrence, and two of these four patients had HPV16-positive post-treatment salivary rinses, showing 50\% sensitivity [48]. On the other hand, among 16 HPV16-positive patients who did not show recurrence, none had HPV16-positive salivary rinses after treatment, showing 100\% specificity. 
Ahn et al. demonstrated that the sensitivity and specificity of pre-treatment HPV DNA detection in saliva in 83 OPC patients, including $72 \mathrm{HPV}$-positive and $11 \mathrm{HPV}$-negative patients, were $53 \%$ and $100 \%$, respectively [21]. Although the sensitivity seems to be relatively low compared with data from a systematic review by Gipson, they reported that four out of 38 OPC patients who were positive for pre-treatment HPV16 DNA had persistently detectable HPV16 DNA in their saliva after treatment [21,46]. In a multivariable analysis, a post-treatment saliva HPV-positive status was associated with a higher risk of recurrence (HR, 10.7; 95\% CI, 2.36-48.50) ( $p=0.002)$. Overall survival was reduced among those with a post-treatment saliva HPV-positive status (HR, 25.9; 95\% CI, 3.23-208.00; $p=0.002)$. Rettig et al. prospectively demonstrated that persistent HPV16 DNA was detected in oral rinse samples in five of $124 \mathrm{HPV}$-associated OPC patients, whereas it was detected in 67 of 124 patients in pre-treatment oral rinse samples [36]. Furthermore, patients with persistent HPV16 DNA after treatment showed significantly poorer progression-free survival (HR, 29.7; 95\% CI, 9.0-98.2; $p<0.001)$ and overall survival (HR, 23.5; 95\% CI, $4.7-116.9 ; p<0.001)$ than patients without persistent HPV16 DNA. Although the prognosis was not stated, Yoshida et al. also demonstrated that persistent HPV DNA in oral rises was only detected in one of eight HPV-associated OPC patients without clinically residual disease after treatment [40]. These results suggest that detectable pre-treatment HPV DNA in oral rinses is cleared after treatment, and that persistent HPV DNA is associated with a poorer prognosis.

A larger-scale prospective study was recently published by Fakhry et al. [45]. Of their 396 patients-including 170 (seven HPV-positive and 163 HPV-negative) with oral cancer, 217 (187 HPV-positive and 30 HPV-negative) with OPC, and nine (eight HPV-positive and one HPV-negative) with unknown primary cancer-the sensitivity and specificity of pre-treatment HPV16 DNA in oral rinses were $81 \%$ and $100 \%$, respectively. The detection of tumor-type oral HPV DNA among patients treated with primary radiotherapy with or without chemotherapy decreased from $85 \%$ at baseline to $9 \%$ after the completion of radiotherapy $(p<0.001)$. Interestingly, the tumor-type HPV DNA load decreased rapidly during primary radiotherapy for most patients ( $24 \%$ relative reduction per weekly visit; $p<0.001)$. On the other hand, the prevalence rates of tumor-type oral HPV DNA before and after primary surgical resection were $69 \%$ and $14 \%$, respectively $(p<0.001)$. Furthermore, in the subset of patients who required adjuvant radiotherapy, the prevalence decreased from $70 \%$ to $38 \%$ after surgical resection and then decreased to $1 \%$ after radiotherapy $(p<0.001)$. Significantly lower 2-year overall survival (68\% vs. 95\%, respectively; adjusted HR, 6.61; $95 \%$ CI, 1.86-23.44; $p=0.003)$ and recurrence-free survival (55\% vs. 88\%, respectively; adjusted HR, 3.72; 95\% CI, 1.71-8.09; $p<0.001$ ) were observed among HPV-positive patients with persistent detection of tumor-type HPV in oral rinse samples after treatment than in those without detectable tumor-type HPV in oral rinse samples after treatment. These results suggest that HPV DNA in oral rinse samples rapidly decreases with treatment, and that the persistent detection of HPV DNA in oral rinse samples is associated with poorer survival and recurrence.

\section{Serum HPV Antibodies in HPV-Associated Oropharyngeal Cancer Patients}

Aside from HPV DNA detection, many investigators have also been interested in serum HPV antibodies in HPV-associated cancer, including OPC, as described in a review by Mirghani [49]. Dahlstrom et al. demonstrated significantly higher positive rates of NE2 (86.5\% vs. $61.1 \%$, respectively), E6 (79.2\% vs. $44.4 \%$, respectively), and any E (89.6\% vs. $72.2 \%$, respectively) antibodies in patients with HPV-positive OPC than in those with HPVnegative OPC [50]. In addition, they showed that HRs for both overall and progression-free survival among HPV-positive OPC patients were 0.2 for NE2, 0.3 for E1, and 0.3 for E6 antibody positivity. However, most reports have focused on E6 antibodies. As shown above, the diagnostic significance of E6 antibody elevation may be low due to positivity in nearly half of HPV-negative OPC patients [50]. 
Therefore, the association of pre- or post-treatment E6 antibody titer with the risk of recurrence has been investigated. With respect to pre-treatment serum E6 antibodies, conflicting reports have been published. Koslaova et al. and Fakhry et al. reported that being positive for E6 antibodies was associated with an increased risk of recurrence [33,51]. On the other hand, Lang Kuhs et al., Huang et al., and Dahlstrom et al. showed that positivity for E6 antibodies was associated with a decreased risk of locoregional recurrence and progression-free survival, respectively [50,52,53]. In addition, several studies reported no association between positive E6 antibody and recurrence [54,55]. With respect to posttreatment serum HPV E6 antibody levels, most reports have described no association with recurrence or progression-free survival [50-52,54,55].

Although significant elevations of serum IgG and IgA antibodies against EBV viral capsid antigen (VCA) have been observed in NPC patients, no significant change was noted between patients in continuous remission and those with tumor recurrence [11]. Similarly, serum HPV E6 antibody titers may not reflect tumor status after treatment.

\section{HPV DNA in Oral Rinses of Recurrent Respiratory Papillomatosis Patients}

Another well-known HPV-associated head and neck tumor is recurrent respiratory papillomatosis (RRP) [56]. RRP is recognized as a chronic disease, characterized by papillomatous growths in the airway, predominantly affecting the larynx and trachea. Typically, multiple exophytic lesions are observed in the larynx, resulting in voice disorders, as well as airway obstruction in cases with bulky lesions. Although high-risk types of HPV, predominantly HPV16, are detected in HPV-associated OPC, low-risk types of HPV, mostly HPV6 and HPV11, are detected in RRP. The disease is histologically benign. The age distribution of RRP in Europe is trimodal, with a peak in children at a median age of 7 years and two other peaks in adults at a median age of 35 and 64 years old [57]. Juvenile-onset RRP tends to have a more aggressive clinical course [58]. Therefore, due to repeated and frequent surgical procedures, the clinical impact on patients seems to be comparable to that of OPC.

A preliminary report by Born et al. showed that 25 (93\%) of 27 adult-onset RRP patients were positive for HPV DNA in oral rinses [59]. Furthermore, Hao et al. recently reported that $22(95.6 \%)$ of 23 RRP patients had an initial HPV-positive oral rinse [60]. They also showed that $17(77.2 \%)$ of those 22 patients had an additional positive oral rinse in at least one of samples collected during 6-12 months following the acquisition of the initial rinse [60]. These results suggest that patients with RRP may have an increased propensity to harboring HPV in the oral cavity, as the prevalence of oral HPV infection in the general public is reported to be $6.9 \%(95 \%$ CI, $5.7 \%-8.3 \%)[59,61]$.

One of the interesting and important findings regarding RRP is that HPV DNA was detected in not only tumor tissue, but also in uninvolved sites in patients with active disease and in samples from patients in remission [62]. Therefore, the question of whether HPV DNA is detected in oral rinse samples from patients in remission is of great interest. Although Hao et al. analyzed multiple consecutive oral rinse samples from patients with $\mathrm{RRP}$, the disease status at each time point of the oral rinse collection was not shown [60].

\section{Future Perspective}

There are several possible options available in regard to HPV testing using blood or oral rinse samples (Figure 2). The main risk factor of HPV-positive OPC is high sexual activity. D'Souza et al. stated that increasing the lifetime number of vaginal sex partners and oral sex partners resulted in a significantly high adjusted odds ratio for HPV-positive OPC [30]. HPV testing using blood or oral rinses could be a screening tool in cohorts with a high risk of HPV-associated OPC, including sex workers and patients in clinics for sexually transmitted infections. For this purpose, the improvement of sensitivity, as well as the development of a simple procedure to detect HPV, will be required. Because of the possible presentation of clinical relevance, the further development of a simple procedure to quantitate HPV DNA in plasma and oral rinses is also required. 


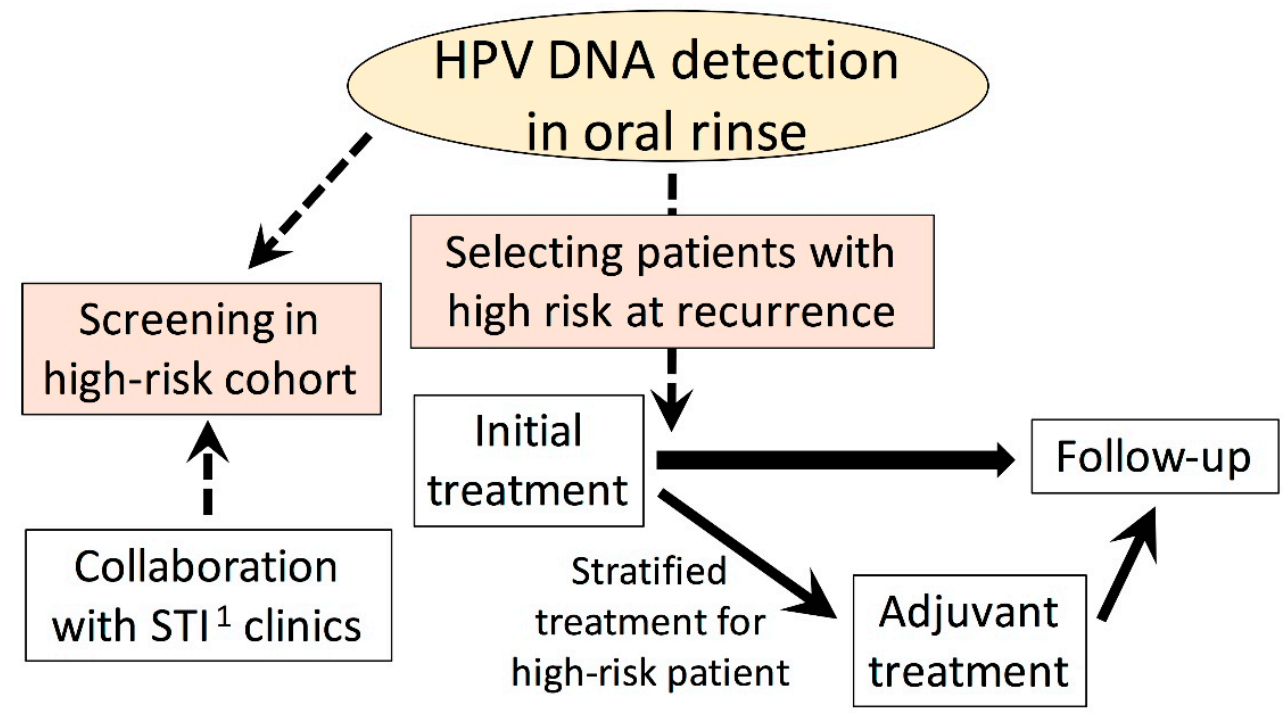

Figure 2. Future perspectives on utilizing HPV DNA detection in oral rinses in clinical settings. ${ }^{1}$ STI, sexually transmitted infection. Modified from [47] with permission by the Society of Oto-Rhino-Laryngology, Tokyo.

Although it is known that HPV-associated OPC patients have a better prognosis than non-HPV-associated OPC patients, it is true that some HPV-associated OPC patients still show a poor prognosis. De-escalation of the treatment intensity for HPV-associated OPC has been vigorously investigated worldwide. However, de-escalated treatment should not be applied for patients with a poor prognosis. Based on the persistence of HPVassociated markers after treatment or the clearance of such markers, it may be appropriate to stratify treatment.

With respect to RRP, no data have been made available as to whether the detection of HPV in oral rinse samples has a significant clinical role. Morphologically apparent RRP can be easily observed through an endoscopy. However, as post-treatment HPV DNA in oral rinses predicts the prognosis of HPV-associated OPC, HPV DNA in oral rinses in patients in remission may predict the recurrence of RRP.

It is inevitable to discuss the various methods used to detect HPV DNA in plasma or oral rinse samples, and to measure the serum HPV titer obtained by various investigators. Recently, D'Souza et al. evaluated biomarker prevalence, and showed that oral rinse HPV testing had moderate-to poor sensitivity for HPV-associated OPC, whereas HPV E6 antibodies showed the best overall test performance [63]. In that study, the most sensitive method of HPV testing in oral rinse samples was HPV DNA detection using the DNA enzyme immuno-assay detection system, which showed 51\% sensitivity and 99\% specificity. As described above, the combined sensitivity of HPV DNA detection in oral rinses was much higher, and even the classic method of auto-nested PCR for HPV DNA, as used by Yoshida et al. and Murono et al., may be more useful $[40,46,64]$. Furthermore, in cervical premalignant diseases, droplet digital PCR (ddPCR) demonstrated a higher HPV DNA detection rate than that of quantitative PCR [65]. Larsson et al. also stated that ddPCR may provide a new promising tool for evaluating the HPV viral load in clinical samples [66]. Accordingly, Isaac et al. used ddPCR to detect HPV DNA in oral rinse samples, and demonstrated high sensitivity, as shown in Table 3 [41]. The establishment of a standardized method is desired and multi-institutional collaboration should be encouraged. Currently, no definitive conclusion can be drawn on this matter. However, further investigations could identify a way to accurately identify patients at risk of both the development and recurrence of HPV-associated OPC. 
Funding: This research received no external funding.

Institutional Review Board Statement: Not applicable.

Informed Consent Statement: Not applicable.

Conflicts of Interest: The author declares no conflict of interest.

\section{References}

1. Murono, S.; Yoshizaki, T.; Tanaka, S.; Takeshita, H.; Park, C.S.; Furukawa, M. Detection of Epstein-Barr virus in nasopharyngeal carcinoma by in situ hybridization and polymerase chain reaction. Laryngoscope 1997, 197, 523-526. [CrossRef]

2. Kondo, S.; Horikawa, T.; Takeshita, H.; Kanegane, C.; Kasahara, Y.; Sheen, T.; Sato, H.; Furukawa, M.; Yoshizaki, T. Diagnostic value of serum EBV-DNA quantification and antibody to viral capsid antigen in nasopharyngeal carcinoma patients. Cancer Sci. 2004, 85, 508-513. [CrossRef]

3. Lo, Y.M.; Chan, L.Y.; Lo, K.W.; Leung, S.F.; Zhang, J.; Chan, A.T.; Lee, J.C.; Hjelm, N.M.; Johnson, P.J.; Huang, D.P. Quantitative analysis of cell-free Epstein-Barr virus DNA in plasma of patients with nasopharyngeal carcinoma. Cancer Res. 1999, 59, 1188-1191.

4. Liu, Y.; Fang, Z.; Liu, L.; Yang, S.; Zhang, L. Detection of Epstein-Barr virus DNA in serum or plasma for nasopharyngeal cancer: A meta-analysis. Genet. Test Mol. Biomark. 2011, 15, 495-502. [CrossRef]

5. Zhang, W.; Chen, T.; Chen, L.; Guo, R.; Zhou, G.; Tang, L.; Mao, Y.; Li, W.; Liu, X.; Du, X.; et al. The clinical utility of plasma Epstein-Barr virus DNA assays in nasopharyngeal carcinoma: The dawn of a new era? A systematic review and meta-analysis of 7836 cases. Medicine 2015, 94, e845. [CrossRef]

6. Dürst, M.; Gissmann, L.; Ikenberg, H.; zur Hausen, H. A papillomavirus DNA from a cervical carcinoma and its prevalence in cancer biopsy samples from different geographic regions. Proc. Natl. Acad. Sci. USA 1983, 80, 3812-3815. [CrossRef]

7. Wang, W.Y.; Twu, C.W.; Chen, H.H.; Jiang, R.S.; Wu, C.T.; Liang, K.L.; Shih, Y.T.; Chen, C.C.; Lin, P.J.; Liu, Y.C.; et al. Long-term survival analysis of nasopharyngeal carcinoma by plasma Epstein-Barr virus DNA levels. Cancer 2013, 119, 963-970. [CrossRef]

8. Lei, K.I.; Chan, L.Y.; Chan, W.Y.; Johnson, P.J.; Lo, Y.M. Diagnostic and prognostic implications of circulating cell-free Epstein-Barr virus DNA in natural killer/T-cell lymphoma. Clin. Cancer Res. 2002, 8, $29-34$.

9. Suzuki, R.; Yamaguchi, M.; Izutsu, K.; Yamamoto, G.; Takada, K.; Harabuchi, Y.; Isobe, Y.; Gomyo, H.; Koike, T.; NK-cell Tumor Study Group; et al. Prospective measurement of Epstein-Barr virus-DNA in plasma and peripheral blood mononuclear cells of extranodal NK/T-cell lymphoma, nasal type. Blood 2011, 118, 6018-6022. [CrossRef] [PubMed]

10. Wang, Z.Y.; Liu, Q.F.; Wang, H.; Jin, J.; Wang, W.H.; Wang, S.L.; Song, Y.W.; Liu, Y.P.; Fang, H.; Ren, H.; et al. Clinical implications of plasma Epstein-Barr virus DNA in early-stage extranodal nasal-type NK/T-cell lymphoma patients receiving primary radiotherapy. Blood 2012, 120, 2003-2010. [CrossRef]

11. Chow, L.Q.M. Head and neck cancer. N. Engl. J. Med. 2020, 382, 60-72. [CrossRef]

12. Ang, K.K.; Harris, J.; Wheeler, R.; Weber, R.; Rosenthal, D.I.; Nguyen-Tân, P.F.; Westra, W.H.; Chung, C.H.; Jordan, R.C.; Lu, C.; et al. Human papillomavirus and survival of patients with oropharyngeal cancer. N. Engl. J. Med. 2010, 363, 24-35. [CrossRef]

13. Global Burden of Disease Cancer Collaboration. Global, regional, and national cancer incidence, mortality, years of life lost, years lived with disability, and disability-adjusted life-years for 32 cancer groups, 1990 to 2015: A systematic analysis for the global burden of disease study. JAMA Oncol. 2017, 3, 524-548. [CrossRef] [PubMed]

14. Chaturvedi, A.K.; Engels, E.A.; Pferffer, R.M.; Hernandez, B.Y.; Xiao, W.; Kim, E.; Jiang, B.; Goodman, M.T.; Sibug-Saber, M.; Cozen, W.; et al. Human Papillomavirus and Rising Oropharyngeal Cancer Incidence in the United States. J. Clin. Oncol. 2011, 29, 4294-4301. [CrossRef]

15. Canfell, K. Towards the global elimination of cervical cancer. Papillomavirus Res. 2019, 8, 100170. [CrossRef]

16. Lei, J.; Ploner, A.; Elfström, K.M.; Wang, J.; Roth, A.; Fang, F.; Sundström, K.; Dillner, J.; Sparén, P. HPV Vaccination and the Risk of Invasive Cervical Cancer. N. Engl. J. Med. 2020, 383, 1340-1348. [CrossRef]

17. Bhatla, N.; Singhal, S. Primary HPV screening for cervical cancer. Best Pract. Res. Clin. Obstet. Gynaecol. 2020, 65, 98-108. [CrossRef]

18. Capone, R.B.; Pai, S.I.; Koch, W.M.; Gillison, M.L.; Danish, H.N.; Westra, W.H.; Daniel, R.; Shah, K.V.; Sidransky, D. Detection and quantitation of human papillomavirus (HPV) DNA in the sera of patients with HPV-associated head and neck squamous cell carcinoma. Clin. Cancer Res. 2000, 6, 4171-4175.

19. Jensen, K.K.; Grønhøj, C.; Jensen, D.H.; von Bucheald, C. Circulating human papillomavirus DNA as a surveillance tool in head and neck squamous cell carcinoma: A systematic review and meta-analysis. Clin. Otolaryngol. 2018, 43, 1242-1249. [CrossRef]

20. Cao, H.; Bahn, A.; Kwok, S.; Shi, X.; Wu, S.; Krakow, T.; Khong, B.; Bavan, B.; Bala, R.; Pinsky, B.A.; et al. Quantitation of human papillomavirus DNA in plasma of oropharyngeal carcinoma patients. Int. J. Radiat. Oncol. Biol. Phys. 2012, 82, e351-e358. [CrossRef]

21. Ahn, S.M.; Chan, J.Y.; Zhang, Z.; Wang, H.; Khan, Z.; Bishop, J.A.; Westra, W.; Kock, W.M.; Califano, J.A. Saliva and plasma quantitative polymerase chain reaction-based detection and surveillance of human papillomavirus-related head and neck cancer. JAMA Otolaryngol. Head Neck Surg. 2014, 140, 846-854. [CrossRef]

22. Dahlstrom, K.R.; Li, G.; Hussey, C.S.; Vo, J.T.; Wei, Q.; Zhao, C.; Sturgis, E.M. Circulating human papillomavirus DNA as a marker for disease extent and recurrence among patients with oropharyngeal cancer. Cancer 2015, 121, 3455-3464. [CrossRef] 
23. Lee, J.Y.; Garcia-Murillas, I.; Cutts, R.J.; De Castro, D.G.; Grove, L.; Hurley, T.; Wang, F.; Nutting, C.; Newbold, K.; Harrington, K.; et al. Predicting response to radical (chemo)radiotherapy with circulating HPV DNA in locally advanced head and neck squamous carcinoma. Br. J. Cancer 2017, 117, 876-883. [CrossRef]

24. Chera, B.S.; Kumar, S.; Beaty, B.T.; Marron, D.; Jefferys, S.; Green, R.; Goldman, E.C.; Amdur, R.; Sheets, N.; Dagan, R.; et al. Rapid clearance profile of plasma circulating tumor HPV type 16 DNA during chemoradiotherapy correlates with disease control in HPV-associated oropharyngeal cancer. Clin. Cancer Res. 2019, 25, 4682-4690. [CrossRef]

25. Pornthanakasem, W.; Shotelersuk, K.; Termrungruanglert, W.; Voravud, N.; Niruthisard, S.; Mutirangura, A. Human papillomavirus DAA in plasma of patients with cervical cancer. BMC Cancer 2001, 1, 2. [CrossRef] [PubMed]

26. Dong, S.M.; Pai, S.I.; Rha, S.H.; Hildesheim, A.; Kurman, R.J.; Schwartz, P.E.; Mortel, R.; McGowan, L.; Greenberg, M.D.; Barnes, W.A.; et al. Detection and quantification of human papillomavirus DNA in the plasma of patients with cervical carcinoma. Cancer Epidemiol. Biomark. Prev. 2002, 11, 3-6.

27. Jeannot, E.; Becette, V.; Campitelli, M.; Calméjane, M.A.; Lappartient, E.; Ruff, E.; Saada, S.; Holmes, A.; Bellet, D.; Sastre-Garau, X. Circulating human papillomavirus DNA detected using droplet digital PCR in the serum of patients diagnosed with early stage human papillomavirus-associated invasive carcinoma. J. Pathol. Clin. Res. 2016, 2, 201-209. [CrossRef]

28. Cheung, T.H.; Yim, S.F.; Yu, M.Y.; Worley, M.J., Jr.; Fiascone, S.J.; Chiu, R.W.K.; Lo, K.W.K.; Siu, N.S.S.; Wong, M.C.S.; Yeung, A.C.M.; et al. Liquid biopsy of HPV DNA in cervical cancer. J. Clin. Virol. 2019, 114, 32-36. [CrossRef]

29. Smith, E.M.; Ritchie, J.M.; Summersgill, K.F.; Klussmann, J.P.; Lee, J.H.; Wang, D.; Haugen, T.H.; Turek, L.P. Age, sexual behavior and human papillomavirus infection in oral cavity and oropharyngeal cancers. Int. J. Cancer 2004, 108, 766-772. [CrossRef] [PubMed]

30. D'Souza, G.; Kreimer, A.R.; Viscidi, R.; Pawlita, M.; Fakhry, C.; Koch, W.M.; Westra, W.H.; Gillison, M.L. Case-control study of human papillomavirus and oropharyngeal cancer. N. Engl. J. Med. 2007, 356, 1944-1956. [CrossRef]

31. Gillison, M.L.; D'Souza, G.; Westra, W.; Sugar, E.; Xiao, W.; Begum, S.; Viscidi, R. Distinct risk factor profiles for human papillomavirus type 16-positive and human papillomavirus type 16-negative head and neck cancers. J. Natl. Cancer Inst. 2008, 100, 407-420. [CrossRef]

32. Agrawal, Y.; Koch, W.M.; Xiao, W.; Westra, W.H.; Trivett, A.L.; Symer, D.E.; Gillison, M.L. Oral human papillomavirus infection before and after treatment for human papillomavirus 16-positive and human papillomavirus 16-negative head and neck squamous cell carcinoma. Clin. Cancer Res. 2008, 14, 7143-7150. [CrossRef]

33. Koslabova, E.; Hamsikova, E.; Salakova, M.; Klozar, J.; Foltynova, E.; Salkova, E.; Rotnaglova, E.; Ludvikova, V.; Tachezy, R. Markers of HPV infection and survival in patients with head and neck tumors. Int. J. Cancer. 2013, 133, 1832-1839. [CrossRef]

34. D'Souza, G.; Gross, N.D.; Pai, S.I.; Haddad, R.; Anderson, K.S.; Rajan, S.; Gerber, J.; Gillison, M.L.; Posner, M.R. Oral human papillomavirus (HPV) infection in HPV-positive patients with oropharyngeal cancer and their partners. J. Clin. Oncol. 2014, 32, 2408-2415. [CrossRef]

35. Dang, J.; Feng, Q.; Eaton, K.D.; Jang, H.; Kiviat, N.B. Detection of HPV in oral rinse samples from OPSCC and non-OPSCC patients. BMC Oral Health. 2015, 15, 126. [CrossRef]

36. Rettig, E.M.; Wentz, A.; Posner, M.R.; Gross, N.D.; Haddad, R.I.; Gillison, M.L.; Fakhry, C.; Quon, H.; Sikora, A.G.; Stott, W.J.; et al. Prognostic implication of persistent human papillomavirus type 16 DNA detection in oral rinses for human papillomavirus-related oropharyngeal carcinoma. JAMA Oncol. 2015, 1, 907-915. [CrossRef] [PubMed]

37. Tsao, A.S.; Papadimitrakopoulou, V.; Lin, H.; Guo, M.; Lee, J.J.; Holsinger, F.C.; Hong, W.K.; Sturgis, E.M. Concordance of oral HPV prevalence between patients with oropharyngeal cancer and their partners. Infect. Agent Cancer. 2016, 11, 21. [CrossRef] [PubMed]

38. Chai, R.C.; Lim, Y.; Frazer, I.H.; Wan, Y.; Perry, C.; Jones, L.; Lambie, D.; Punyadeera, C. A pilot study to compare the detection of HPV-16 biomarkers in salivary oral rinses with tumour p16(INK4a) expression in head and neck squamous cell carcinoma patients. BMC Cancer. 2016, 16, 178. [CrossRef]

39. Imai, T.; Sato, I.; Matsumoto, K.; Asada, Y.; Kato, K.; Sogai, S.; Watanabe, K.; Sadayasu, R.; Saijo, S.; Matsuura, K. Human papilloma virus detection in oropharyngeal cancer with gargle samples. B-ENT 2016, 12, 263-269.

40. Yoshida, H.; Murono, S.; Ueno, T.; Nakanishi, Y.; Tsuji, A.; Hatano, M.; Endo, K.; Kondo, S.; Sugimoto, H.; Wakisaka, N.; et al. Usefulness of human papillomavirus detection in oral rinse as a biomarker of oropharyngeal cancer. Acta Otolaryngol. 2017, 137, 773-777. [CrossRef]

41. Isaac, A.; Kostiuk, M.; Zhang, H.; Lindsay, C.; Makki, F.; O'Connell, D.A.; Harris, J.R.; Cote, D.W.; Seikaly, H.; Biron, V.L. Ultrasensitive detection of oncogenic human papillomavirus in oropharyngeal tissue swabs. J. Otolaryngol. Head Neck Surg. 2017, 46, 5. [CrossRef]

42. Rosenthal, M.; Huang, B.; Katabi, N.; Migliacci, J.; Bryant, R.; Kaplan, S.; Blackwell, T.; Patel, S.; Yang, L.; Pei, Z.; et al. Detection of HPV related oropharyngeal cancer in oral rinse specimens. Oncotarget. 2017, 8, 109393-109401. [CrossRef]

43. Wasserman, J.K.; Rourke, R.; Purgina, B.; Caulley, L.; Dimitroulakos, J.; Corsten, M.; Johnson-Obaseki, S. HPV DNA in saliva from patients with SCC of the head and neck is specific for p16-positive oropharyngeal tumours. J. Otolaryngol. Head Neck Surg. 2017, 46, 3. [CrossRef]

44. Tang, K.D.; Baeten, K.; Kenny, L.; Frazer, I.H.; Scheper, G.; Punyadeera, C. Unlocking the potential of saliva-based test to detect HPV-16-deriven oropharyngeal cancer. Cancers 2019, 11, 473. [CrossRef] [PubMed] 
45. Fakhry, C.; Blackford, A.L.; Neuner, G.; Xiao, W.; Jiang, B.; Agrawal, A.; Gillison, M.L. Association of oral human papillomavirus DNA persistence with cancer progression after primary treatment for oral cavity and oropharyngeal squamous cell carcinoma. JAMA Oncol. 2019, 5, 985-992. [CrossRef]

46. Gipson, B.J.; Robbins, H.A.; Fakhry, C.; D'Souza, G. Sensitivity and specificity of oral HPV detection for HPV-positive head and neck cancer. Oral Oncol. 2018, 77, 52-56. [CrossRef]

47. Murono, S. Viral DNA as a biomarker of nasopharyngeal and oropharyngeal cancers. Oto-Rhino-Laryngol. Tokyo 2019, 62, 252-260.

48. Chuang, A.Y.; Chuang, T.C.; Chang, S.; Zhou, S.; Begum, S.; Westra, W.H.; Ha, P.K.; Koch, W.M.; Califano, J.A. Presence of HPV DNA in convalescent salivary rinses is an adverse prognostic marker in head and neck squamous cell carcinoma. Oral Oncol. 2008, 44, 915-919. [CrossRef]

49. Mirghani, H.; Lang Kuhs, K.A.; Waterboer, T. Biomarkers for early identification of recurrences in HPV-driven oropharyngeal cancer. Oral Oncol. 2018, 82, 108-114. [CrossRef]

50. Dahlstrom, K.R.; Anderson, K.S.; Cheng, J.N.; Chowell, D.; Li, G.; Posner, M.; Sturgis, E.M. HPV serum antibodies as predictors of survival and disease progression in patients with HPV-positive squamous cell carcinoma of the oropharynx. Clin. Cancer Res. 2015, 21, 2861-2869. [CrossRef]

51. Fakhry, C.; Qualliotine, J.R.; Zhang, Z.; Agrawal, N.; Gaykalova, D.A.; Bishop, J.A.; Subramaniam, R.M.; Koch, W.M.; Chung, C.H.; Eisele, D.W.; et al. Serum antibodies to HPV16 early proteins warrant investigation as potential biomarkers for risk stratification and recurrence of HPV-associated oropharyngeal cancer. Cancer Prev. Res. 2016, 9, 135-141. [CrossRef]

52. Lang Kuhs, K.A.; Kreimer, A.R.; Trivedi, S.; Holzinger, D.; Pawlita, M.; Pfeiffer, R.M.; Gibson, S.P.; Schmitt, N.C.; Hildesheim, A.; Waterboer, T.; et al. Human papillomavirus $16 \mathrm{E} 6$ antibodies are sensitive for human papillomavirus-driven oropharyngeal cancer and are associated with recurrence. Cancer 2017, 123, 4382-4390. [CrossRef]

53. Huang, C.G.; Lee, L.A.; Liao, C.T.; Yen, T.C.; Yang, S.L.; Liu, Y.C.; Li, J.C.; Gong, Y.N.; Kang, C.J.; Huang, S.F.; et al. Molecular and serologic markers of HPV 16 infection are associated with local recurrence in patients with oral cavity squamous cell carcinoma. Oncotarget 2017, 8, 34820-34835. [CrossRef]

54. Spector, M.E.; Sacco, A.G.; Bellile, E.; Taylor, J.M.G.; Jones, T.; Sun, K.; Brown, W.C.; Birkeland, A.C.; Bradford, C.R.; Wolf, G.T.; et al. E6 and E7 antibody levels are potential biomarkers of recurrence in patients with advanced-stage human papillomavirus-positive oropharyngeal squamous cell carcinoma. Clin. Cancer Res. 2017, 23, 2723-2729. [CrossRef]

55. Zhang, Y.; Waterboer, T.; Haddad, R.I.; Miles, B.A.; Wentz, A.; Gross, N.D.; Fakhry, C.; Quon, H.; Lorch, J.H.; Gourin, C.G.; et al. Human papillomavirus (HPV) 16 antibodies at diagnosis of HPV-related oropharyngeal cancer and antibody trajectories after treatment. Oral Oncol. 2017, 67, 77-82. [CrossRef]

56. Mounts, P.; Shah, K.V.; Kashima, H. Viral etiology of juvenile- and adult-onset squamous papilloma of the larynx. Proc. Natl. Acad. Sci. USA 1982, 79, 5425-5429. [CrossRef] [PubMed]

57. San Giorgi, M.R.; van den Heuvel, E.R.; Tjon Pian Gi, R.E.; Brunings, J.W.; Chirila, M.; Friedrich, G.; Golusinski, W.; Graupp, M.; Horcasitas Pous, R.A.; Ilmarinen, T.; et al. Age of onset of recurrent respiratory papillomatosis: A distribution analysis. Clin. Otolaryngol. 2016, 41, 448-453. [CrossRef]

58. Buchinsky, F.J.; Valentino, W.L.; Ruszkay, N.; Powell, E.; Derkay, C.S.; Seedat, R.Y.; Uloza, V.; Dikkers, F.G.; Tunkel, D.E.; Choi, S.S.; et al. Age at diagnosis, but not HPV type, is strongly associated with clinical course in recurrent respiratory papillomatosis. PLoS ONE 2019, 14, e0216697. [CrossRef]

59. Born, H.; Ruiz, R.; Verma, A.; Taliercio, S.; Achlatis, S.; Pitman, M.; Gandonu, S.; Bing, R.; Amin, M.R.; Branski, R.C. Concurrent oral human papilloma virus infection in patients with recurrent respiratory papillomatosis: A preliminary study. Laryngoscope 2014, 124, 2785-2790. [CrossRef]

60. Hao, Y.; Ruiz, R.; Yang, L.; Neto, A.G.; Amin, M.R.; Kelly, D.; Achlatis, S.; Roof, S.; Bing, R.; Kannan, K.; et al. Mitochondrial somatic mutations and the lack of viral genomic variation in recurrent respiratory papillomatosis. Sci. Rep. 2019, 9, 16625. [CrossRef]

61. Gillison, M.L.; Broutian, T.; Pickard, R.K.; Tong, Z.Y.; Xiao, W.; Kahle, L.; Graubard, B.I.; Chaturvedi, A.K. Prevalence of oral HPV infection in the United States, 2009-2010. JAMA 2012, 307, 693-703. [CrossRef]

62. Steinberg, B.M.; Topp, W.C.; Schneider, P.S.; Abramson, A.L. Laryngeal papillomavirus infection during clinical remission. N. Engl. J. Med. 1983, 308, 1261-1264. [CrossRef]

63. D'Souza, G.; Clemens, G.; Troy, T.; Castillo, R.G.; Struijk, L.; Waterboer, T.; Bender, N.; Pierorazio, P.M.; Best, S.R.; Strickler, H.; et al. Evaluating the utility and prevalence of HPV biomarkers in oral rinses and serology for HPV-related oropharyngeal cancer. Cancer Prev. Res. 2019, 12, 689-700. [CrossRef] [PubMed]

64. Murono, S.; Yoshida, H.; Kobayashi, T.; Kawase, T.; Kikuchi, D.; Suzuki, T.; Nakanishi, Y.; Endo, K.; Kondo, S.; Wakisaka, N.; et al. Multifocal human papillomavirus detection in palatine and pharyngeal tonsils. Acta Otolaryngol. 2018, 138, 483-486. [CrossRef] [PubMed]

65. Rotondo, J.C.; Oton-Gonzalez, L.; Mazziotta, C.; Lanzillotti, C.; Iaquinta, M.L.; Tognon, M.; Martini, F. Simultaneous detection and viral DNA load quantification of different human papillomavirus type in clinical specimens by the high analytical droplet digital PCR method. Front. Microbiol. 2020, 11, 591452. [CrossRef] [PubMed]

66. Larsson, G.L.; Helenius, G. Digital droplet PCR (ddPCR) for the detection and quantification of HPV 16, 18, 33 and 45-A short report. Cell Oncol. 2017, 40, 521-527. [CrossRef] 